\title{
Study of nitrate leaching and nitrogen fate under intensive vegetable production pattern in northern China
}

\author{
Song Xiao-Zong a, ${ }^{a}$, Zhao Chang-Xing ${ }^{\text {c,d,* }}$, Wang Xiao-Lan ${ }^{a}$, Li Ji ${ }^{a, *}$ \\ ${ }^{a}$ College of Resources and Environmental Sciences, China Agricultural University, Beijing 100193, China \\ b Soil and Fertilizer Institute, Shandong Academy of Agricultural Sciences, Tsinan 250100, China \\ ${ }^{\mathrm{c}}$ College of Agriculture and Plant Protection, Qingdao Agricultural University, Qingdao 266109, Shandong, China \\ d State Key Laboratory of Urban and Regional Ecology, Research Center for Eco-Environmental Sciences, \\ Chinese Academy of Sciences, Beijing 100085, China
}

Received 19 September 2008; accepted after revision 24 November 2008

Available online 31 January 2009

Presented by Philippe Morat

\begin{abstract}
Because of intensive vegetable production in plastic greenhouses in northern China, the potential risk of nitrate leaching to groundwater is increasingly apparent, threatening ecosystem services and the sustainability of food production. In the present work, nine drainable lysimeters were installed into vegetable fields, with in-situ loamy soils, in Shouguang City of the north China vegetable base. The experiments were conducted to quantify the magnitude and variability of nitrate leaching to groundwater and to access the fate of total fertilizer- $\mathrm{N}$ inputs in the area. The results obtained indicated that: under local conventional agronomic practices, there is a high discrepancy in leaching nitrate- $\mathrm{N}$ concentration (ranging from 17 to $457 \mathrm{mg} \mathrm{L}^{-1}$ ), and nitrate losses (152-347 $\mathrm{kg} \mathrm{Nha}^{-1}$ ) were observed from 1-m soil profiles in the field. Meanwhile, high fertilizer $\mathrm{N}$ application resulted in low N efficiency, with only $(33.0 \pm 13) \%$ (mean \pm S.D.) of input $\mathrm{N}$ absorbed by the crops, while additionally nearly half of the total inputs of $\mathrm{N}$ were unaccounted in a partial $\mathrm{N}$ balance sheet. It is concluded that groundwater pollution associated with greenhouse-based vegetable production had been confirmed in Shouguang, adversely affecting water quality and leading to serial agro-ecological problems. To cite this article: X.-Z. Song et al., C. R. Biologies 332 (2009).
\end{abstract}

(C) 2008 Académie des sciences. Published by Elsevier Masson SAS. All rights reserved.

Keywords: Nitrate leaching; Groundwater; Nitrate concentration; Nitrogen balance; Intensive vegetable production

\section{Introduction}

A dramatic increase of synthetic fertilizer nitrogen (N) consumption has occurred in the world during the past 40 years [1-3]. Today, to meet the food demands

\footnotetext{
* Corresponding author.

E-mail addresses: zhaochangxing@126.com (C.-X. Zhao), liji@cau.edu.cn (J. Li).
}

of 1.3 billion people, China has become the largest $\mathrm{N}$ consumer in the world, with approximately $22 \mathrm{Tg}$ $\left(\mathrm{Tg}=10^{12} \mathrm{~g}\right)$ of synthetic $\mathrm{N}$ fertilizer in 2002. Substantial $\mathrm{N}$ fertilizer application to farmland has led to many environmental problems, such as groundwater contamination, and this was especially serious in intensive vegetable cultivation areas in China. Nitrate pollution to groundwater became the potentially prominent threat to the health of the local population [4-7]. At present, 
people clearly know that the source of contamination is mainly from overuse of commercial $\mathrm{N}$ fertilizer in agricultural production areas; however, $\mathrm{N}$ must be added to the soil to sustain food, feed, and fiber production.

A range of study patterns has been developed to evaluate nitrate pollution to date. Lysimeter have been successfully used in numerous case studies to measure nitrate leaching in agricultural ecosystems [8-11]. Several empirical or conceptual models, in conjunction with suction cup studies, were established to simulate nitrate leaching through unsaturated soil and to describe nitrogen transformation [12-15]. On-the-spot investigations on groundwater were another direct and effective pattern to evaluate nitrate contamination [5,16-18]. Of all the nitrate studies, there is a great discrepancy between developed and developing countries. Data showed that nearly two-thirds of the total $\mathrm{N}$ was consumed in the developing countries [1]. A substantial quantity of fertilizer was misused, and squandered on the soil for the lack of agricultural information and technology. As the largest $\mathrm{N}$ consumer, there are active demands for policy and technical support to agricultural production in China, but unfortunately, few study works have been made to evaluate and measure nitrate pollution to the agricultural ecosystem.

Intensive vegetable crop cultivation is highly susceptible to nitrate loss via leaching [19]. In China, groundwater $\mathrm{N}$ contamination has also caused much concern, especially in regions with intensive agricultural produc-

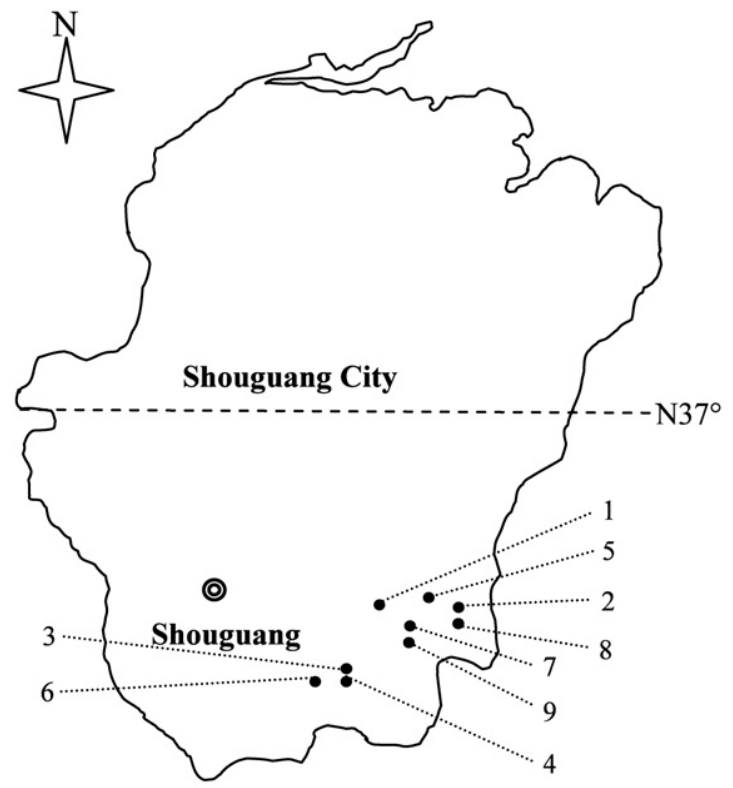

tion, such as intensive vegetable production. Drinking water in the plain comes exclusively from groundwater sources and, therefore, keeping its nitrate- $\mathrm{N}$ below the maximum contaminant level is important. However, few field studies have determined the losses of nitrate due to leaching from vegetable crops receiving different N-based fertilizers until recent years [20]. Drainable lysimeter offers a direct approach to monitoring nitrate leaching to groundwater [2,21]. In this study, lysimeter was first introduced to intensive greenhouse vegetable production in China.

The objectives of this paper were to: (i) ascertain how much of $\mathrm{N}$ is lost, and when leaching is most likely to occur, under traditional management practices; (ii) evaluate a partial $\mathrm{N}$ balance in protected vegetable fields. The present study will assist people to identify scenarios susceptible to groundwater nitrate- $\mathrm{N}$ contamination, minimize nitrate leaching, and improve those aspects of the current $\mathrm{N}$ management to better fertigation practices.

\section{Materials and methods}

\subsection{Research site description}

The field experiment was conducted on nine representative, typical fields in Shouguang $\left(118^{\circ} 44^{\prime} \mathrm{E}\right.$ longitude and $36^{\circ} 52^{\prime} \mathrm{N}$ latitude), Shandong Province (Fig. 1). Precipitation averages $593.8 \mathrm{~mm} \mathrm{year}^{-1}$ (from 1964 to

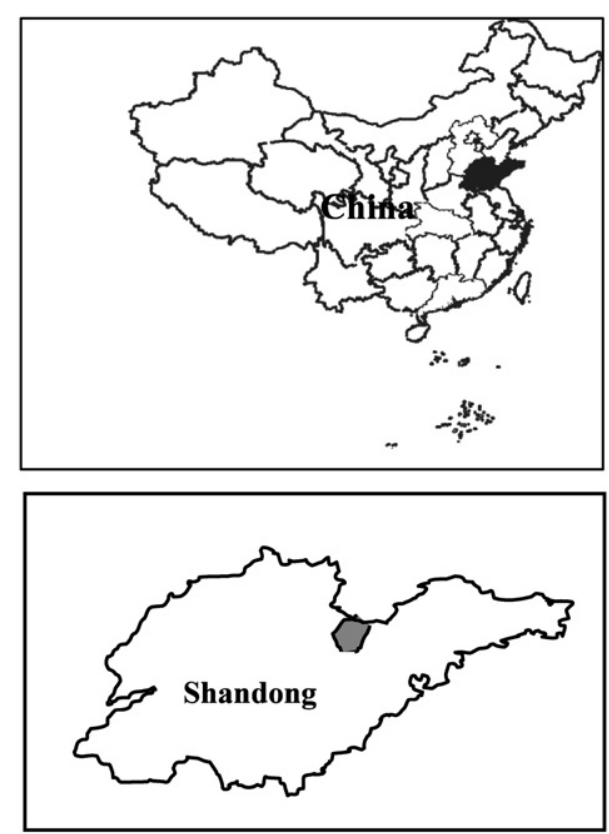

Fig. 1. Location of the study sites in Shouguang, Shandong, China. 
Table 1

Crops planted in, and some properties of 9 greenhouses investigated.

\begin{tabular}{|c|c|c|c|c|c|}
\hline Field & Village name & Planting crop & $\begin{array}{l}\text { Acreage } \\
\left(\mathrm{m}^{2}\right)\end{array}$ & Farming years & $\begin{array}{l}\text { Growing period } \\
\text { (d) }\end{array}$ \\
\hline 1 & Changleying & Casaba & 700 & 4 & 90 \\
\hline 2 & Tanhe & Hot pepper & 500 & 1 & 70 \\
\hline 3 & Zaohu & Hami cantaloupe/Yardlong cowpea & 540 & 1 & 130 \\
\hline 4 & Zaohu & Hami cantaloupe & 540 & 6 & 70 \\
\hline 5 & Hegou & Cucumber & 589 & 6 & 110 \\
\hline 6 & Songjiazhuang & Casaba & 540 & 4 & 80 \\
\hline 7 & Guanlu & Tomato & 506 & 2 & 120 \\
\hline 8 & Tanhe & Sweet pepper & 730 & 2 & 110 \\
\hline 9 & Guanlu & Hot pepper & 350 & 9 & 130 \\
\hline
\end{tabular}

/ indicates interplanting.

Table 2

Soil properties from nine vegetable fields.

\begin{tabular}{|c|c|c|c|c|c|c|c|}
\hline \multirow{2}{*}{$\begin{array}{l}\text { Soil depth } \\
(\mathrm{cm})\end{array}$} & \multicolumn{3}{|c|}{ Soil texture ${ }^{*}(\%)$} & \multirow{2}{*}{$\begin{array}{l}\text { Bulk density } \\
\left(\mathrm{g} \mathrm{cm}^{-1}\right)\end{array}$} & \multirow{2}{*}{$\begin{array}{l}\text { Total N } \\
\left(\mathrm{g} \mathrm{kg}^{-1}\right)\end{array}$} & \multirow{2}{*}{$\begin{array}{l}\text { Organic C } \\
\left(\mathrm{g} \mathrm{kg}^{-1}\right)\end{array}$} & \multirow{2}{*}{$\begin{array}{l}\mathrm{pH} \\
\left(\mathrm{H}_{2} \mathrm{O} 1: 1\right)\end{array}$} \\
\hline & $\begin{array}{l}\text { Sand } \\
(2-0.05 \mathrm{~mm})\end{array}$ & $\begin{array}{l}\text { Silt } \\
(0.05-0.002 \mathrm{~mm})\end{array}$ & $\begin{array}{l}\text { Clay } \\
(<0.002 \mathrm{~mm})\end{array}$ & & & & \\
\hline $0-30$ & $36 \pm 5$ & $61 \pm 5$ & $3 \pm 1$ & $1.22 \pm 0.22$ & $0.8 \pm 0.3$ & $11.2 \pm 5.2$ & $6.7 \pm 0.4$ \\
\hline $30-60$ & $31 \pm 7$ & $65 \pm 6$ & $3 \pm 1$ & $1.22 \pm 0.11$ & $0.4 \pm 0.1$ & $6.8 \pm 4.8$ & $6.8 \pm 0.3$ \\
\hline $60-100$ & $32 \pm 12$ & $64 \pm 11$ & $4 \pm 1$ & $1.24 \pm 0.14$ & $0.3 \pm 0.1$ & $4.9 \pm 3.0$ & $6.9 \pm 0.2$ \\
\hline
\end{tabular}

* Classification from USDA (United States Department of Agriculture).

2004) with most of the annual precipitation occurring from June to August. It has an area of $2180 \mathrm{~km}^{2}$, and protected vegetable cultivation accounts for up to $55 \%$ of the arable land area use, as it is a major vegetable production base in China. For the semiarid climate, groundwater is the major source for agricultural irrigation and for drinking water. Because of the cover of polyethylene film, there is no rainfall input to the field in the plastic greenhouses and the internal temperature ranged from 12 to $45^{\circ} \mathrm{C}$ annually, with a mean of $25^{\circ} \mathrm{C}$ [7]. Furrow irrigation is typically used in the region. Major management practices applied to each plot are summarized in Table 1, and some physical and chemical properties of soil from the experimental sites are listed in Table 2.

\subsection{Lysimeter installation and meteorological measurements}

Nine foursquare drainable lysimeters $\left(1 \mathrm{~m}^{2}\right)$ were installed in the field of nine plastic greenhouses in November 2004, as described by Gasser et al. [22]. On the ground above the lysimeter, two-row crops were planted with a $0.6-\mathrm{m}$ space in a $0.8-\mathrm{m}$ bed. A $2.5-\mathrm{cm}-$ diameter hose links the lysimeter to the collection vessel. The access device was a 2-m-long, 160-mm-diameter Polyvinyl Chloride (PVC) tube, which was mostly buried in the soil with its 20 -cm upper part above the ground. The seepage water from each lysimeter was collected in the PVC tube, from which a sample was taken for $\mathrm{N}$ analysis. Then the container was emptied for the next collection. Uniform agricultural management practices were conducted between lysimeter and the surrounding plot in the plastic greenhouse [11,22].

Temperature, rainfall, and other meteorological parameters were monitored at an automated weather station located less than $0.5 \mathrm{~km}$ from the field site. All the climatic sensors were installed at $1.5 \mathrm{~m}$ above ground level.

\subsection{Sampling and data collection}

Various $\mathrm{N}$ fertilizer sources are available for vegetable crops, but under the farmer's routine management practices, these fertilizer products, other than base fertilizers (mainly manures), must be highly soluble and fast-release $\mathrm{N}$ sources so that they can be applied to soils in conjunction with furrow irrigation.

Leachate samples from soil profile were collected fortnightly during the growing season, or more frequently as needed, depending on the irrigation schedule. Irrigation water was measured with a water meter and sampled directly from the irrigation hose at monthly intervals throughout the whole cropping season. Plastic bottles $(50 \mathrm{ml})$ were filled with the water samples, immediately frozen and transported to the laboratory for 
storage until thawed prior to $\mathrm{N}$ analysis. $\mathrm{N}$ leaching losses were calculated from the product of nitrate and ammonium concentrations and water fluxes.

Soil mineral $\mathrm{N}\left(\mathrm{NH}_{4}-\mathrm{N}\right.$ and $\left.\mathrm{NO}_{3}-\mathrm{N}\right)$ was measured by sampling soils using a soil auger at the beginning and end of the cropping season. Nine soil cores were obtained from each soil layer $(0-30,30-60,60-100 \mathrm{~cm})$ using recommended procedures for vegetable fields. Samples were immediately saved in a plastic foamedlined box at $4{ }^{\circ} \mathrm{C}$, transported to the laboratory for storage and analysis.

Fertilizer $\mathrm{N}$ input was calculated from application rates and $\mathrm{N}$ content of each fertilizer product. Crop $\mathrm{N}$ was estimated from stochastic sampling of ten labeled plants at the beginning of the growing season. The selected plants were separated into stems, leaves and fruits (without consideration of residues below the ground) in for total $\mathrm{N}$ determination using the recommended procedure. Irrigated $\mathrm{N}$ input was calculated from cumulative amounts and $\mathrm{N}$ content of irrigation water for each time.

\subsection{Laboratory measurements and analysis}

Soil texture was determined using Laser Grain-size analyzer (Mastersizer 2000, MALVERN), and the other properties were surveyed by conventional measuring methods. Total plant $\mathrm{N}$ was measured using an automated Kjeldahl digestion procedure.

Nitrate and ammonium in leachate and irrigation water were determined using colorimeter procedures on a scientific instruments continuous flowing analytical system (TRAACS 2000). Mineral $\mathrm{N}$ in soil samples were extracted using $0.01 \mathrm{M} \mathrm{CaCl}_{2}$ solution (soil: solution ratios of 1:10), shaken for $1 \mathrm{~h}$, and filtrated to a $50-\mathrm{mL}$ plastic bottle for frozen storage until nitrate and ammonium analysis. Plant straw samples were oven-dried at $70^{\circ} \mathrm{C}$ and ground to a $0.5-\mathrm{mm}$ powder.

\subsection{Mass balance}

A partial mineral $\mathrm{N}$ balance equation $[13,22,23]$ was introduced for each greenhouse by considering inputs $(\mathrm{N}$ from mineral organic fertilizers, and irrigation wa- ter), outputs (leached $\mathrm{N}$ and crop $\mathrm{N}$ exported at harvest) and soil mineral $\mathrm{N}$ variations $(0-100 \mathrm{~cm})$ for a cropping season. Other nitrogen unaccounted in the balance sheet includes $\mathrm{N}$ from mineralization/immobilization, ammonia volatilization and denitrification, and was estimated by difference:

$$
N_{m f}+N_{o f}+N_{i r}=N_{c}+N_{l}+N_{u}+\Delta N_{s m}
$$

where $N_{m f}$ is mineral $\mathrm{N}$ fertilizer inputs, $N_{o f}$ is organic $\mathrm{N}$ fertilizer inputs, $N_{i r}$ is irrigating water $\mathrm{N}$ inputs, $N_{c}$ is crop $\mathrm{N}$ exported at harvest, $N_{l}$ is leached $\mathrm{N}, N_{u}$ is unaccounted $\mathrm{N}$, and $\Delta N_{s m}$ is soil mineral $\mathrm{N}$ variation.

All statistical analyses were performed using SPSS version 11.5.

\section{Results and discussion}

\subsection{Irrigation}

From late February to early March, the nine fields were cultivated, fertilized and irrigated in company with plants explanting. There is an obvious discrepancy in the total irrigation levels among the nine fields during the growing season (Table 3). Field 1 received the minimum amount, a total of $492 \mathrm{~mm}$ water, while the maximum irrigation water of $1446 \mathrm{~mm}$ was applied to field 9, a nearly two-fold excess quantity. This could be attributed to differences in growing days and management practices of the growers. Throughout the whole cropping season, a similar water amount for each irrigation event was applied to individual fields, but different irrigation times, ranging from 7 to 12 times for the nine fields, resulted in apparent differences of total irrigation water amounts.

\subsection{Percolation rates}

Because of the limited volume of the collection vessel, seepage water was collected and sampled 2-3 times for each irrigation event. However, in most cases, the water percolation occurred within 3 days and then little and even no water collection occurred, until the advent of the next irrigation event.

Table 3

Water irrigation amounts and leached water flux from 9 fields.

\begin{tabular}{|c|c|c|c|c|c|c|c|c|c|c|c|}
\hline \multirow[t]{2}{*}{ Field } & 1 & 2 & 3 & 4 & 5 & 6 & 7 & 8 & 9 & \multirow[t]{2}{*}{ Average } & \multirow[t]{2}{*}{ S.D. } \\
\hline & CLY & $\mathrm{TB}$ & $\mathrm{ZB}$ & $\mathrm{ZN}$ & HG & $S$ & GB & $\mathrm{TN}$ & GN & & \\
\hline Irrigation amounts (mm) & 492 & 659 & 1024 & 665 & 846 & 1216 & 516 & 1121 & 1446 & 887 & 334 \\
\hline Leached water flux (mm) & 100 & 82 & 129 & 71 & 97 & 119 & 89 & 104 & 102 & 99 & 18 \\
\hline$\%$ & 20 & 12 & 13 & 11 & 12 & 10 & 17 & 9 & 7 & 12 & 4 \\
\hline
\end{tabular}


Table 4

Average nitrate concentration of water samples from 9 lysimeters during a growing season $\left(\mathrm{mg} \mathrm{N} \mathrm{L}^{-1}\right)$.

\begin{tabular}{|c|c|c|c|c|c|c|c|c|c|c|c|c|c|c|}
\hline \multirow[t]{2}{*}{ Field } & \multicolumn{12}{|c|}{ Sampling no. } & \multirow[t]{2}{*}{ Average } & \multirow[t]{2}{*}{ S.D } \\
\hline & 1 & 2 & 3 & 4 & 5 & 6 & 7 & 8 & 9 & 10 & 11 & 12 & & \\
\hline 1 & 61 & 110 & 133 & 181 & 184 & 280 & 160 & 210 & & & & & 165 & 66 \\
\hline 2 & 22 & 42 & 108 & 135 & 195 & 220 & 357 & & & & & & 100 & 70 \\
\hline 3 & 26 & 33 & 110 & 138 & 145 & 179 & 200 & 189 & 167 & 151 & 155 & 139 & 136 & 55 \\
\hline 4 & 125 & 205 & 240 & 194 & 248 & 213 & 283 & & & & & & 215 & 50 \\
\hline 5 & 81 & 150 & 130 & 172 & 305 & 320 & 290 & 202 & & & & & 206 & 89 \\
\hline 6 & 45 & 230 & 380 & 277 & 320 & 300 & 340 & 380 & 330 & 293 & & & 289 & 97 \\
\hline 7 & 30 & 114 & 205 & 184 & 200 & 210 & 234 & 215 & 233 & & & & 181 & 67 \\
\hline 8 & 17 & 43 & 90 & 225 & 150 & 145 & 180 & 200 & 235 & 250 & & & 154 & 81 \\
\hline 9 & 50 & 60 & 69 & 222 & 457 & 385 & 330 & 380 & 349 & 260 & & & 256 & 150 \\
\hline
\end{tabular}

Total amounts of irrigation water inputs and leaching water losses are summarized in Table 3. Compared with the large amounts of irrigation water, little but a steady flow of water was percolated beyond the 1-m soil profile during the growing season. Total water leaching losses ranged from 54 to $129 \mathrm{~mm}$, accounting for $(12 \pm 4) \%$ (mean \pm S.D.) of the total irrigation water. This was similar to some reports [24,25], but greatly lower than results in other previous studies $[7,15]$. In case of field 1, a high seepage level of water, $100 \mathrm{~mm}$, was collected, despite the smallest amount of total irrigation water application, while only $102 \mathrm{~mm}$ of seepage water was collected from field 9 with the largest irrigation water input. This can be explained by the fact that high evapo-transpiration resulted in quick water losses in the form of gas under the internal microclimate of the plastic greenhouse; in addition, a loamy soil caused a slower percolation rate of water. Therefore, relatively little water was collected from the soil profile.

\subsection{Nitrate leaching concentration}

The mineral concentrations $\mathrm{N}$ of water samples from each lysimeter were determined. As expected, the ammonium concentration for seepage water was shown to maintain a relatively low level $\left(<10 \mathrm{mg} \mathrm{NL}^{-1}\right)$ in comparison with nitrate content, and thus nitrate was regarded as the $\mathrm{N}$ leaching losses.

Of all the water samples from the nine drainable lysimeters, nitrate concentrations were uniformly higher than $10 \mathrm{mg} \mathrm{L}^{-1}$, the acceptable standard level for drinking water. Despite the differences among the nine fields, a variation trend of partial normal distribution in nitrate concentration of water leachates was observed, Table 4. At the beginning of the seedling stage, from the grower's perspective, the plant has a weak nutrient demand and thus little or no additional fertilizer application was needed. Due to this, a relative low nitrate level was observed. In this period, $\mathrm{N}$ residues in the soil profile from the previous crop rotation and base fertilizers mainly contributed to leaching $\mathrm{N}$ losses. In addition, a higher initial nitrate concentration of seepage water was observed in fields 4 and 5, which received large quantities of barnyard manure (duck) and diammonium orthophosphate, respectively. As time went on, soluble organic and inorganic $\mathrm{N}$ fertilizers were applied to the field along with irrigation [26]; meanwhile, the high temperature and the low $\mathrm{C} / \mathrm{N}$ ratio enhanced the $\mathrm{N}$ mineralization and leaching under the internal microclimate in the plastic greenhouse. All the above factors resulted in the increasing nitrate concentration from seepage water.

We can observe that a hysteresis effect of input $\mathrm{N}$ variation on nitrate leaching was recorded and it reflected on the concentration fluctuation of water leachates in comparison to the foregoing irrigation event during the growing season (Table 4). It indicated that temporal $\mathrm{N}$ application did not immediately find expression in seepage water, but occurred at the next irrigation event. This phenomenon apparently focused on the peak nitrate concentration for each lysimeter throughout the cropping season, which indicated the maximum $\mathrm{N}$ application in conjunction with the last irrigation event. Under local practices, sustainable fertilizer applications were synchronized with the growth of the commercial vegetable products. Once crop productivity declined at the harvest anaphase, economic consideration caused little or no nutrient application to the soil with only irrigating water input. This explained the decrease of nitrate concentration. During this period, the source of nitrate leaching comes from the applied fertilizer $\mathrm{N}$ residues and mineralization of manures and soil organic matter. 
Table 5

Nitrogen rates $\left(\mathrm{kg} \mathrm{ha}^{-1}\right)$ distribution balance for a cropping season.

\begin{tabular}{|c|c|c|c|c|c|c|c|c|c|c|c|c|c|}
\hline \multirow{3}{*}{$\begin{array}{l}\text { Green- } \\
\text { house }\end{array}$} & \multicolumn{6}{|c|}{$\mathrm{N}$ inputs } & \multirow[t]{3}{*}{ Total } & \multicolumn{4}{|c|}{$\mathrm{N}$ outputs } & \multirow{3}{*}{$\begin{array}{l}\text { Soil mineral } \\
\mathrm{N}^{\mathrm{a}} \text { variation }\end{array}$} & \multirow{3}{*}{$\begin{array}{l}\text { Unaccounted } \\
\mathrm{N}\end{array}$} \\
\hline & \multicolumn{2}{|c|}{$\begin{array}{l}\text { Mineral } \\
\text { fertilizer } \\
\end{array}$} & \multicolumn{2}{|c|}{$\begin{array}{l}\text { Organic } \\
\text { fertilizer }\end{array}$} & \multicolumn{2}{|c|}{$\begin{array}{l}\text { Irrigation } \\
\text { water }\end{array}$} & & \multicolumn{2}{|c|}{$\begin{array}{l}\text { Nitrate } \\
\text { leaching }\end{array}$} & \multicolumn{2}{|c|}{$\begin{array}{l}\text { Crop } \\
\text { uptake }\end{array}$} & & \\
\hline & Rate & $\%$ & Rate & $\%$ & Rate & $\%$ & & Rate & $\%$ & Rate & $\%$ & & \\
\hline 1 & 325 & 68 & 8 & 2 & 144 & 30 & 579 & 169 & 29 & 219 & 38 & -39 & 231 \\
\hline 2 & 190 & 30 & 170 & 27 & 268 & 43 & 493 & 154 & 31 & 227 & 46 & -3 & 115 \\
\hline 3 & 493 & 38 & 310 & 24 & 482 & 38 & 1316 & 261 & 20 & 298 & 23 & -48 & 806 \\
\hline 4 & 207 & 31 & 154 & 23 & 300 & 45 & 694 & 152 & 22 & 122 & 18 & -225 & 645 \\
\hline 5 & 501 & 58 & 190 & 22 & 169 & 20 & 973 & 199 & 20 & 289 & 30 & -50 & 535 \\
\hline 6 & 504 & 39 & 185 & 14 & 603 & 47 & 1296 & 347 & 27 & 196 & 15 & 63 & 690 \\
\hline 7 & 300 & 57 & 166 & 32 & 59 & 11 & 552 & 158 & 29 & 296 & 54 & -75 & 173 \\
\hline 8 & 328 & 56 & 186 & 32 & 73 & 12 & 565 & 155 & 27 & 244 & 43 & -232 & 401 \\
\hline 9 & 391 & 34 & 240 & 21 & 523 & 45 & 1060 & 255 & 24 & 366 & 35 & -514 & 953 \\
\hline Average & 360 & 46 & 179 & 22 & 298 & 32 & 836 & 183 & 22 & 251 & 33 & -125 & 528 \\
\hline
\end{tabular}

a Variation in soil mineral $\mathrm{N}$ content $(100 \mathrm{~cm}$ depth).

\subsection{Nitrate leaching losses}

Nitrate leaching losses were calculated for all the fields. Since the similar seepage water rates for each time were collected from the individual lysimeter, even if under various irrigation events during the growing season, nitrate leaching depended mainly on the $\mathrm{N}$ content of water leachates. Therefore, the similar variation trends occurred in $\mathrm{N}$ leaching losses for each field. In addition, the irrigation schedules suitable for different growing period of various vegetable crops also resulted in differences in cumulative nitrate leaching losses, ranging from 152 to $347 \mathrm{~kg} \mathrm{Nha}^{-1}$ (Table 5). In comparison, Romas [13] reviewed a predicted equation for nitrate leaching losses in vegetable production as follows:

$\mathrm{N}_{L}=0.20 \times\left(\mathrm{N}_{i} \times \mathrm{D}\right)^{0.712}$

where $\mathrm{N}_{L}$ is the nitrate leached, $\mathrm{N}_{i}$ is the $\mathrm{N}$ input $\left(\mathrm{kg} \mathrm{ha}^{-1}\right)$, and $\mathrm{D}$ is the drainage $(\mathrm{cm})$. Using the above method, the calculated leaching $\mathrm{N}$ ranged from 55 to $206 \mathrm{~kg} \mathrm{ha}^{-1}$, with a mean value of $122 \mathrm{~kg} \mathrm{ha}^{-1}$. These results were usually less than actual data collected in our study. This can be explained since higher temperature and evaportranspiration in the plastic greenhouse greatly decreased leaching water drainage, compared to the open field with no artificial cover.

\subsection{Partial $N$ balance}

Under the local traditional management practices, vegetable crops receive frequent fertilizer applications, which totaled from 333 to $803 \mathrm{~kg} \mathrm{ha}^{-1}$ (Table 5). For the nine fields, the applied fertilizer $\mathrm{N}$ greatly exceeded the crop uptake $\mathrm{N}$, ranging from 122 to $366 \mathrm{~kg} \mathrm{ha}^{-1}$. Additional $\mathrm{N}$ from irrigation varied from 59 to $603 \mathrm{~kg} \mathrm{ha}^{-1}$ for various fields during the growing season. The initial and final amounts of soil mineral $\mathrm{N}$ was determined at the beginning and end of the cropping season. Data showed that the initial N contents in the soil profiles were significantly different between the fields before planting. Previous works in this region showed that large variability in $\mathrm{N}$ contents of $1.2-\mathrm{m}$ soil profile between different culturing years $[27,28]$. The soil mineral $\mathrm{N}$ variation was mostly negative values, ranging from -3 to $-514 \mathrm{~kg} \mathrm{ha}^{-1}$, indicating the $\mathrm{N}$ losses from the 1-m soil column. A previous study showed that the rational ratio of total input $\mathrm{N}$ to crop $\mathrm{N}$ is $2: 1$ [29], but in this study, it was much higher than the limit, with mean 3.8:1.

A linear regression is observed in this experiment between leaching $\mathrm{N}$ loss and total $\mathrm{N}$ surplus in nine fields (Fig. 2). The slope indicates that about $18 \%$ of each $\mathrm{N}$ unit input is leached out of the root zone and maybe go downwards to the groundwater. The intercept would mean a net value of $78 \mathrm{~kg} \mathrm{Nha}^{-1} \mathrm{~N}$ loss comes from previous residue $\mathrm{N}$ and soil organic matter, even if no $\mathrm{N}$ is added by growers.

After a cropping season survey period, a partial balance sheet was built up and listed at Table 5. In each partial balance sheet for the nine vegetable fields, the proportion of crop exported mean $(33 \pm 13) \%$ (mean \pm S.D.) of total $\mathrm{N}$ inputs, and nitrate leaching losses accounted for $(26 \pm 8) \%(12-40 \%)$. Other N "losses" were included in unaccounted $\mathrm{N}$. The highest mineral $\mathrm{N}$ fertilizer use and the highest well water $\mathrm{N}$ input were recorded for field 6, which brought the highest leaching losses and a low level of crop N. Also, a higher amount of organic fertilizer (duck manure) was applied 


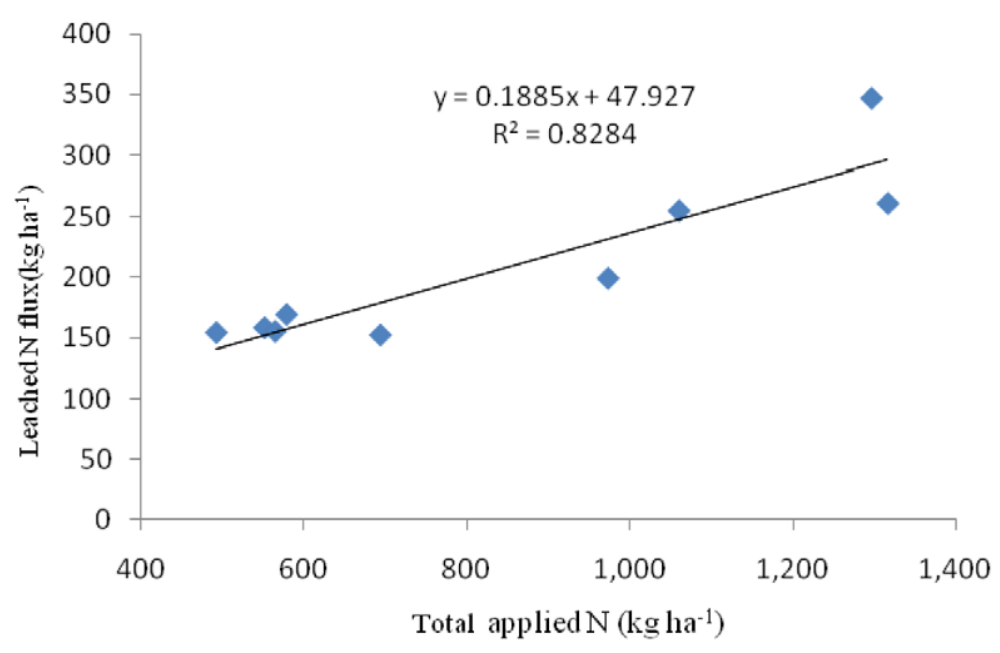

Fig. 2. A linear trend between total applied $\mathrm{N}$ and leached $\mathrm{N}$ flux.

to soils as base fertilizer. However, it greatly exceeded the crop requirement and resulted to the lowest fertilizer efficiency. Conversely, the lowest mineral fertilizer $\mathrm{N}$ and low total $\mathrm{N}$ use for field 2 had the lowest nitrate leaching losses. This result was in harmony with other studies $[3,22,30]$. Approximately half of total $\mathrm{N}$ inputs were unutilized as the unaccounted $\mathrm{N}$.

Irrigation also had a great effect on nitrate leaching (Table 5). $\mathrm{N}$ from irrigation water, usually ignored, now accounted for an important proportion, ranging from $11 \%$ to $47 \%$ with an average $32 \%$ of total input N. A monthly survey of irrigation water of nine fields showed that nitrate $\mathrm{N}$ concentration ranged between 5$82 \mathrm{mg} \mathrm{L}^{-1}$, in most case greater than $10 \mathrm{mg} \mathrm{L}^{-1}$, indicating serious nitrate pollution to groundwater. Another recent investigation on 15 specific shallow wells in intensive vegetable cultivation areas showed a nearly 3-fold increase in N content of groundwater since 1996 [6]. In China, vegetable plastic greenhouses are usually located around the rural village for easy access, and this enhances the potential threat to the health of the local population.

\section{Conclusion}

These results revealed that under local agricultural practices, traditional fertilizer $\mathrm{N}$ application greatly exceeded the capacity of crop uptake and inevitably led to massive nitrate-N getting into groundwater during intensive vegetable production. Drastic nitrate leaching losses were observed with high nitrate concentrations in seepage water from drainable lysimeters during a growing reason. A partial mineral $\mathrm{N}$ balance sheet confirmed only $33 \%$ of the total $\mathrm{N}$ inputs were utilized by the crops with low fertilizer $\mathrm{N}$ efficiency. $\mathrm{N}$ loss of nitrate leaching ranged from 152 to $347 \mathrm{~kg} \mathrm{Nha}^{-1}$, which gave a large load to the unsaturated soil profile and groundwater. In addition, survey on specific shallow wells confirmed present nitrate contamination to groundwater in the experimental sites.

In our perspective, frequent irrigation and high fertilizer $\mathrm{N}$ application resulted in low fertilizer efficiency and high nitrate leaching losses at present. Further studies should be conducted to assess whether and to what extent the traditional cultivation practices can be revised to an optimum level without yield decline. Best management alternatives integrating local agronomic practices should be recommended to local government to be implemented as detailed legislative policy, but this needs time. In our opinion, delay and conservative $\mathrm{N}$ application, integrated with a reasonable irrigation schedule can be suggested as an effective and necessary solution to alleviate nitrate leaching.

\section{Acknowledgements}

This research was supported by the National Ecology Key Project of Beijing (XK10019440), Urban Agriculture project of Beijing (XK100190553), National Nature Science Foundation of China (No. 40701077), China's Post-doctoral Science Fund (No. 20080430567).

\section{References}

[1] FAOSTAT, Agricultural Data, are available on the World Wide Web: http://www.apps.fao.org/cgi-bin/nphdb.pl?, F.A.O. (United Nations Food and Agricultural Organization), 1999.

[2] J.N. Galloway, W.H. Schlesinger, H.I.I. Levy, A. Michaels, J.L. Schnoor, Nitrogen fixation: Anthropogenic enhancement- 
environmental response, Global Biogeochem. Cycl. 9 (1995) 235-252.

[3] A.R. Mosier, M.A. Bleken, P. Chaiwanakupt, E.C. Ellis, J.R. Freney, R.B. Howarth, P.A. Matson, K. Minami, R. Naylor, K.N. Weeks, Z.L. Zhu, Policy implications of human-accelerated nitrogen cycling, Biogeochem. 57-58 (2002) 477-516.

[4] T.M. Addiscott, A.P. Whitmore, D.S. Powlson, in: Farming, Fertilizers and the Nitrate Problem, C.A. B International, Wallingford, 1991, pp. 1-14.

[5] W.L. Zhang, Z.X. Tian, N. Zhang, X.Q. Li, Nitrate pollution of groundwater in north China, Agri. Ecosys. Environ. 59 (1996) 223-231.

[6] Z.H. Liu, Studies on use of chemical fertilizer, pesticides and environmental impact on groundwater in vegetable cultivation area, Ph.D. dissertation. China Agricultural University, Resources and Environment Faculty, Beijing, 2001.

[7] J.H. Zhu, Study on Fate and Utilization of Nitrogen in Protected Vegetable Fields, China Agricultural University, Resources and Environment Faculty, Beijing, 2002.

[8] L. Prunty, B.R. Montgomery, Lysimeter study of nitrogen and irrigation rates on quality of recharge water and corn yield, J. Environ. Qual. 20 (1991) 373-380.

[9] J.D. Toth, R.H. Fox, Nitrate losses from a corn-alfalfa rotation: Lysimeter measurement of nitrate leaching, J. Environ. Qual. 27 (1998) 1027-1033.

[10] S. Knappe, U. Haferkorn, R. Meissner, Influence of different agricultural management systems on nitrogen leaching: results of lysimeter studies, J. Plant Nutri. Soil Sci. 165 (2002) 73-77.

[11] R. Meissner, J. Seeger, H. Rupp, Lysimeter studies in East Germany concerning the influence of set aside of intensively farmed land on the seepage water quality, Agri. Ecosys. Environ. 67 (1998) 161-173.

[12] T. Darwish, T. Atallah, S. Hajhasan, A. Chranek, Management of nitrogen by fertigation of potato in Lebanon, Nutr. Cycl. Agroecosys. 67 (2003) 1-11.

[13] C. Ramos, A. Agut, A.L. Lidón, Nitrate leaching in important crops of the Valencian Community region (Spain), Environ. Pol. 118 (2002) 215-223.

[14] K.L. Hu, Spatial variability of soil properties and stochastic simulation of nitrate leaching in field scale, Ph.D. dissertation, China Agricultural University, Resources and Environment Faculty, Beijing, 2000.

[15] J.T. Waddle, S.C. Gupta, J.F. Moncrief, C.J. Rosen, D.D. Steele, Irrigation- and nitrogen-management impacts on nitrate leaching under potato, J. Environ. Qual. 29 (2000) 251-261.

[16] J. Mohsen, Nitrate leaching from agricultural land in Hamadon, western Iran, Agri. Ecosys. Environ. 110 (2005) 210-218.
[17] J.F. Power, J.S. Schepers, Nitrate contamination of groundwater in North America, Agriculture, Ecosystems and Environment AEENDO 26 (1989) 165-187.

[18] S. Gül, H. Özcan, E. Sire, Nitrate contamination of the lower Seyhan plain in Turkey, Fre. Environ. Bull. 13 (2004) 398-404.

[19] L.E. Jackson, L.J. Wyland, L.J. Stivers, Winter cover crops to minimize nitrate losses during a short fallow period, J. Agri Sci. 121 (1993) 55-62.

[20] H.M. Yu, Z.Z. Li, Y.S. Gong, Leached nitrate in vegetable field under different water and nitrogen fertilizer management practices, Sci. Agri. Sin. 38 (2005) 1849-1855.

[21] L. Prunty, R. Greenland, Nitrate leaching using two potato-corn $\mathrm{N}$-fertilizer plans on sandy soil, Agri. Ecosys. Environ. 65 (1997) $1-13$.

[22] M.O. Gasser, M.R. Laverdiere, R. Lagace, J. Caron, Impact of potato-cereal rotation and slurry applications on nitrate leaching and nitrogen balance in sandy soils, Canadian J. Soil Sci. 82 (2002) 469-479.

[23] B.T. Sexton, J.F. Moncrief, C.J. Rosen, S.C. Gupta, H.H. Cheng, Optimizing nitrogen and irrigation inputs for corn based on nitrate leaching and yield on a coarse-textured soil, J. Environ. Qual. 25 (1996) 982-992.

[24] U.D. Mack, K.H. Feger, Y. Gong, K. Stahr, Soil water balance and nitrate leaching in winter wheat-summer maize doublecropping systems with different irrigation and $\mathrm{N}$ fertilization in the North China Plain, J. Plant Nutr. Soil Sci. 168 (2005) 454 460.

[25] K. Kengni, G. Vachaud, J.L. Thony, R. Laty, B. Garino, H. Casabianca, P. Jame, R. Viscogliosi, Field measurements of water and nitrogen losses under irrigated maize, J. Hydrol. 162 (1994) 23-46.

[26] S.L. Tisdale, W.L. Nelson, J.D. Beaton, J.L. Havlin, Soil Fertility and Fertilizers, 5th ed., MacMillan, New York, 1993.

[27] J. Li, D. Cui, X. Meng, X.L. Li, F.S. Zhang, The study of fertilization condition and question in protectorate vegetable in Shouguang, Shandong, Chin. J. Soil Sci. 33 (2002) 126-128.

[28] W. Li, M. Zhang, H. Li, L. Zan, The study of soil nitrate status in fields under plastic house gardening, Acta Pedol. Sin. 39 (2002) 283-287.

[29] C.R. Frink, P.E. Waggoner, J.H. Ausubel, Nitrogen fertilizer: retrospect and prospect, Proceedings of the National Academy of Sciences of the United States of America 96 (1999) 1175-1180.

[30] C.S.M. Olsthoorn, N.P.K. Fong, The anthropogenic nitrogen cycle in the Netherlands, Nutrient Cycling in Agroecosystems 52 (1998) 269-276. 